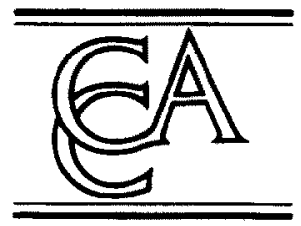

\title{
Regulation of transferrin receptor expression and distribution in in vitro cultured human cytotrophoblasts
}

\author{
J. Sander Starreveld, Hans P. van Dijk, Martin J. Kroos, \\ Henk G. van Eijk* \\ Department of Chemical Pathology, Erasmus University Rotterdam, P.O. Box 1738, 3000 DR \\ Rotterdam, The Netheriands
}

(Received 10 December 1992; revision received 28 April 1993; accepted 13 May 1993)

\begin{abstract}
During gestation the transplacental iron transport is very important to the fetus. Iron uptake by the placenta can be studied in cultured cytotrophoblasts. The influence of culture time and human diferric transferrin on the number and distribution of transferrin receptors (TRRs) was investigated in human cytotrophoblasts. Cytotrophoblasts cultured for $2.5 \mathrm{~h}$ had few TfRs $(0.28 \mathrm{pmol} / \mathrm{mg}$ protein). With time, total TfR amounts increase $(4.14 \mathrm{pmol} / \mathrm{mg}$ protein at $70 \mathrm{~h}$ ). They increase to a higher level in cells cultured in iron-poor medium, indicating that iron has an effect on the TfR synthesis/breakdown ratio. TfRs were distributed between two 'active' (located at the cell surface and intracellularly) and one 'inactive' (located intracellularly) receptor pools. TfR distribution among these pools was modulated by culture time and iron. Trophoblasts regulated iron uptake by variation of number of surface TfRs via changes in total TfRs and redistribution of TfRs among the receptor pools.
\end{abstract}

Key words: Iron; Transferrin receptor; Placenta; Cytotrophoblast

\section{Introduction}

The principal function of transferrin (hTf) is the transport of iron in the circulation $[1,2,3]$. hTf is taken up by the cells via receptor-mediated endocytosis $[4,5]$. hTf

\footnotetext{
* Corresponding author.
} 
binds to transferrin receptors (TfRs) which are clustered in coated pits [6]; the coated pits are internalized by forming endosomes. These vesicles become acidic [4,7], iron is released from transferrin and the apo hTf-TfR complex is recycled back to the cell surface. In response to the environmental $\mathrm{pH}$ of 7.4 apo hTf dissociates from its receptor leaving both ready to be re-used. This mechanism of iron uptake is among others $[8,9]$ found in trophoblasts [10].

A variable percentage of TfRs are found within cells [11,12]. TfRs participating in the endocytic cycle are found both on the cell surface and within cells. Apart from these two metabolically active subgroups a further TfR pool has been proposed by Hirose-Kumagai and Akamatsu [13]. This pool, also located intracellularly, is functionally inactive.

In several cell types TfR and ferritin synthesis are simultaneously, though inversely, controlled by the intracellular iron concentrations [14]. Regulation takes place at the translational level by means of iron responsive elements on the mRNA for TfR and ferritin [15]. This regulation mechanism, however, has not yet been identified in trophoblasts.

Because high intracellular iron concentrations are potentially dangerous and the fact that transplacental transport of iron increases enormously during pregnancy, the uptake of iron has to be balanced very precisely. Furthermore, the fetus does not suffer from iron-induced anaemia, even if the maternal iron stores are depleted [16-18], so a regulation mechanism for iron transport is likely to exist [19]. Bierings et al. [20] suggested that the iron transport may be regulated by the alteration of surface TfR numbers similar to the variation of surface TfRs by HeLa cells [21].

Surface TfR numbers could be regulated firstly by a change in the synthesis/ breakdown ratio and secondly by redistribution of TfRs among (functionally) different pools. Both mechanisms might occur simultaneously. Redistribution of TfRs has been confirmed in several cell types [22-26] and might be influenced by the number of TfRs located in intracellular pools [27].

The cell layer primarily involved in the transplacental transport of iron is the syncytium formed by syncytiotrophoblasts. In situ syncytiotrophoblasts differentiate out of cytotrophoblasts which are proliferative throughout gestation. During this differentiation process, cells start with the production of specific hormones (hCG, hPL and SP-1) [28,29].

As a model of the maternal fetal interface cultured cytotrophoblasts were used. Cytotrophoblasts in culture do not proliferate though they differentiate into syncytiotrophoblast-like cells which can be concluded from the production of syncytiotrophoblast-specific hormones $[28,30-32]$ and the expression of TfRs $[10,33,34]$.

Biochemical differentiation and morphological differentiation do not necessarily occur simultaneously $[30,33]$. Even the parameters of the biochemical differentiation do not necessarily parallel each other [20].

In cultured cytotrophoblasts, TfR expression not only depends on culture time but also on the supplementation of iron $[20,35]$. In this study we investigated the influence of culture time (differentiation state) and hTf-2Fe availability on total TfR expression and on the distribution of TfRs between endocytic active and inactive TfR pools. The relevance for the regulation of iron transfer and the maintenance of low intracellular (free) iron concentrations is discussed. 


\section{Materials and methods}

\subsection{Chemicals}

Calcium and magnesium free solution of Earle's Balanced Salts (CMFS), fetal calf serum (FCS), Medium 199 (M199), penicillin, streptomycin and amphotericin were obtained from Flow Labs., (ICN Biomedicals, Zoetermeer, Netherlands). Gentamycin was from Schering Corp., USA, trypsin (1:250 t.c.) from Sigma Chemical Company, St. Louis, MO and DNase grade II from Boehringer Mannheim, Germany. Apo transferrin was from Behring Werke, Marburg, Germany. $\mathrm{Na}^{125} \mathrm{I}$ was obtained from Radiochemical Centre Amersham, UK. Iodo-Gen was from Pierce Chemical Co., USA. All chemicals were of the highest purity available.

\subsection{Iodination}

Fully saturated transferrin was obtained using iron-nitrilotriacetate (Fe-NTA) (ratio $1 \mathrm{~mol} \mathrm{Fe}$ to 2 mol NTA) and a 10-fold molar excess of bicarbonate as the synergistic anion (buffered in $0.1 \mathrm{M}$ Tris- $\mathrm{HCl}, \mathrm{pH}$ 8.2). The excess of Fe-NTA was removed on a PD-10 Sephadex column (Pharmacia, Uppsala, Sweden) and by extensive dialysis against Tris- $\mathrm{HCl}$ buffer $(\mathrm{pH} \mathrm{8.2)}$. The iron saturation of the transferrin was checked by measuring the E470/E280 ratio which was always 0.045 , indicating full saturation. One milligram of this diferric transferrin was incubated with ${ }^{125} \mathrm{I}$ $(0.5 \mathrm{mCi})$ for $20 \mathrm{~min}$ at room temperature in a glass vial coated with $100 \mu \mathrm{g}$ IodoGen. Free ${ }^{125} \mathrm{I}$ was separated from radiolabelled transferrin on a PD-10 Sephadex column, followed by extensive dialysis against phosphate buffered saline (PBS) (136.8 mM NaCl, $2.68 \mathrm{mM} \mathrm{KCl}, 8.10 \mathrm{mM} \mathrm{Na} \mathrm{HPO}_{4}, 1.14 \mathrm{mM} \mathrm{KH}_{2} \mathrm{PO}_{4} ; \mathrm{pH} 8.2$ ). The final specific activity of the diferric ${ }^{125}$ I-labelled transferrin varied between 230 and $535 \times 10^{6}$ counts/min per mg protein.

\subsection{Trophoblast-cell isolation}

Normal human placentae were obtained (from the Department of Obstetrics, Academic Hospital Rotterdam/Dijkzigt, Rotterdam) within $0.5 \mathrm{~h}$ after spontaneous delivery. These placentae were essentially processed as described by Hall et al. [36] in combination with a Percoll gradient described by Kliman et al. [28], except for the addition of $\mathrm{CaCl}_{2} \cdot 2 \mathrm{H}_{2} \mathrm{O}(1 \mathrm{mM})$ and $\mathrm{MgSO}_{4} \cdot 7 \mathrm{H}_{2} \mathrm{O}(0.8 \mathrm{mM})$ to the enzyme solution [20]. By this procedure a cell population was isolated consisting of at least $95 \%$ cytotrophoblasts [28] which has been reconfirmed in our laboratory by immunocytochemical staining using a panel of monoclonal antibodies [33]. Furthermore the percentage of hCG, hPL and SP-1 producing cells was revealed by immunocytochemical staining. $[33,36]$. In the present experiments one culture dish was routinely checked for the number of cells positive for hCG production. In all experiments at least $95 \%$ of the cells became positive for hCG production after $40 \mathrm{~h}$. Cells obtained were counted (using a Burker counting-chamber), diluted to $6 \times 10^{5} \mathrm{cells} / \mathrm{ml}$ in culture medium and plated out in $35 \mathrm{~mm}$ Falcon culture dishes (Greiner and Söhne, Germany) $\left(1.5 \times 10^{6}\right.$ cells/dish). Culture medium consisted of 80 volume $\%$ M199 (Flow Labs), 20 volume \% FCS, $4 \mathrm{mM}$ L-glutamine, $0.3 \mathrm{mg} / \mathrm{ml}$ gentamycin, 50.0 $\mathrm{IU} / \mathrm{ml}$ penicillin, $50.0 \mu \mathrm{g} / \mathrm{ml}$ streptomycin and $2.50 \mu \mathrm{g} / \mathrm{ml}$ amphotericin. Osmolality was $280-300 \mathrm{mmol} / \mathrm{kg}, \mathrm{pH} 7.4$. The medium was sterilized by filtration through a 0.22- $\mu \mathrm{m}$ Millipore-GS filter (Millipore SA Molsheim, France). Cultures were incubated at $37^{\circ} \mathrm{C}$ in humidified $5 \% \mathrm{CO}, / 95 \%$ air. 


\subsection{Cell culture conditions}

Cells were allowed to recover from the isolation procedure for $18-24 \mathrm{~h}$ and subsequently washed twice with M199 to remove non-adherent cells. The cells used for TfR determination after $2.5 \mathrm{~h}$ were handled in a similar way. Cell culture was continued in fresh, identical culture medium or the same medium supplemented with human diferric transferrin ( $\mathrm{hTf}-2 \mathrm{Fe}$ ) in humidified $5 \% \mathrm{CO}_{2} / 95 \%$ air at $37^{\circ} \mathrm{C}$. The culture medium was changed every $24 \mathrm{~h}$. The 0-passage of cells was used for the experiments, which were generally started $18-20 \mathrm{~h}$ after cell isolation.

\subsection{Binding essays}

To minimize the interference of residual receptor bound transferrin, cells were preincubated for $15 \mathrm{~min}$ (at $37^{\circ} \mathrm{C}$ in $5 \% \mathrm{CO}_{2} / 95 \%$ air) in $\mathrm{M} 199$ without additives. Finally they were re-chilled to $4^{\circ} \mathrm{C}$ and washed twice with PBS.

Surface transferrin receptor population. To measure the number of cell surface TfRs, cells were incubated for $1.5 \mathrm{~h}$ at $4^{\circ} \mathrm{C}$ (long enough to reach equilibrium) with a concentration of $125 \mathrm{nM}{ }^{125}$ I-labelled diferric transferrin ( $\left.{ }^{125} \mathrm{I}-\mathrm{hTf}-2 \mathrm{Fe}\right), \mathrm{A}$ transferrin concentration of ten times $K_{D}$ would give a $90 \%$ saturation [37]. The concentration used by us was 60 times $K_{\mathrm{D}}$. Under these conditions full saturation was reached [36]. Non-specific binding was measured by addition of a 100-times excess of unlabelled diferric transferrin and never exceeded $25 \%$ of the total binding of ${ }^{125} \mathrm{I}-\mathrm{hTf}-2 \mathrm{Fe}$. Non-specific binding amounting up to $25 \%$ is rather high for ligand concentrations used in Scatchard analysis. However, at the ligand concentrations used, it is not extreme. The cells were then washed three times with ice-cold PBS to remove unbound ${ }^{125} \mathrm{I}-\mathrm{hTf}-2 \mathrm{Fe}$. Finally cells were lysed by addition of distilled water and collected with a rubber 'Policeman'. Surface bound radioactivity was assessed using a Packard 500C autogamma spectrometer. TfRs were calculated from the amount of specifically bound ${ }^{125} \mathrm{I}-\mathrm{hTf}-2 \mathrm{Fe}$.

Total transferrin receptor population. Cultured cells were washed three times with ice-cold PBS and lysed in $0.5 \mathrm{ml} 0.1 \%$ Triton X-100. Lysis was checked using an inversion microscope (CK2, Olympus, Japan). The detergent 'Triton X-100' has widely been used in receptor binding studies and no effects have been reported on plasma membrane receptors [13]. Cell suspensions were collected in pre-weighed tubes and homogenized by sonication for $10 \mathrm{~s}$ in melting ice. Tubes were re-weighed to ascertain the sample volume. Of the cell lysates portions of $0.1 \mathrm{ml}$ were taken for protein determination. Cell lysates were incubated with ${ }^{125} \mathrm{I}-\mathrm{hTf}-2 \mathrm{Fe}$ (final and saturating concentration $125 \mathrm{nM}$ ) for $1 \mathrm{~h}$ at room temperature. Ammonium sulfate was added in a $1: 1$ volume ratio resulting in a $30 \%\left(\mathrm{NH}_{4}\right)_{2} \mathrm{SO}_{4}$ solution to precipitate the ${ }^{125} \mathrm{I}$ hTf-2Fe-TfR complex [38]. Samples were filtered through $1.2-\mu \mathrm{m}$ glass microfiber filters (GF-C, Whatman) [38]. Filters were rinsed four times with $30 \%\left(\mathrm{NH}_{4}\right)_{2} \mathrm{SO}_{4}$. Radioactivity on the filters was measured as described above. TfR number was calculated from the amount of specifically bound ${ }^{125} \mathrm{I}-\mathrm{hTf}-2 \mathrm{Fe}$. This method was carefully checked for precipitation of unbound ${ }^{125} \mathrm{I}-\mathrm{hTf}-2 \mathrm{Fe}(<0.5 \%)$ (results not shown).

Transferrin receptors participating in the endocytic cycle. Cells were incubated for $1 \mathrm{~h}$ at $37^{\circ} \mathrm{C}$ in medium M199 supplemented with $250 \mathrm{nM}{ }^{125} \mathrm{I}-\mathrm{hTf}-2 \mathrm{Fe}$ and suc- 
cessively washed three times with PBS (pH 7.4) at $4^{\circ} \mathrm{C}$. To remove surface bound hTf-2Fe, acid/neutral washes were carried out at $4^{\circ} \mathrm{C}$; cells were firstly incubated for 10 min with sodium acetate buffer (pH 4.5) and secondly for 10 min with PBS (pH 7.4). This procedure was repeated twice. Finally the cells were lysed in distilled water and collected with a rubber 'Policeman'. Radioactivity in the cell lysates and the combined acid/neutral washes was determined as described above. Non-specific binding was determined by binding of ${ }^{125} \mathrm{I}-\mathrm{hTf}-2 \mathrm{Fe}$ in the presence of a 100-times excess of unlabelled hTf-2Fe. The number of surface-bound TfRs was derived from the acid/neutral wash labile ${ }^{125} \mathrm{I}-\mathrm{hTf}-2 \mathrm{Fe}$. The number of intracellular TfRs was calculated from the amount of radioactivity resistant to the acid/neutral washes.

\subsection{Protein determination}

A homogenous sample was obtained by sonication for $10 \mathrm{~s}$ in melting ice. Protein concentration in the samples containing distilled water was determined according to Bradford [39] with human transferrin as a standard. The samples containing Triton $\mathrm{X}-100$ were analyzed according to Wang and Smith [40].

\subsection{DNA-determination}

DNA contents of the samples were determined with the Nuclesan-100 kit obtained from Sanbio BV, The Netherlands [41].

\section{8. hCG-determination}

Culture medium hCG concentrations were measured using an ES-600 autoanalyzer (Boehriger Mannheim, Germany). The medium was removed at indicated times and replaced by identical culture medium. Prior to analysis the medium was centrifuged for $5 \mathrm{~min}$ at $1,200 \times \mathrm{g}$. Supernatants were used for hCG determination.

\subsection{Statistics}

To estimate the significance of the results the Student's $t$-test was used in experiments with only two groups, the Student-Newman-Keuls test for experiments with more than two groups and for the experiments on receptor distribution the $\chi^{2}$ test was used.

\section{Results}

\subsection{Validity of DNA and protein measurements as reference parameters}

As depicted in Fig. 1, hCG production strongly increased after approximately 40 $\mathrm{h}$ and the total hCG production was comparable with previously presented data $[28,29]$. Together with the absence of TfRs and the fact that over $95 \%$ of the cells were hCG-positive after $40 \mathrm{~h}$ in culture, this was taken as evidence that the initially attached cell population was highly enriched with cytotrophoblasts.

Culture-dish protein content varied (from 50 up to $150 \mu \mathrm{g}$ per dish) between samples isolated from different placentae. The variance in protein concentration between samples prepared from cells isolated from one placenta was small and 


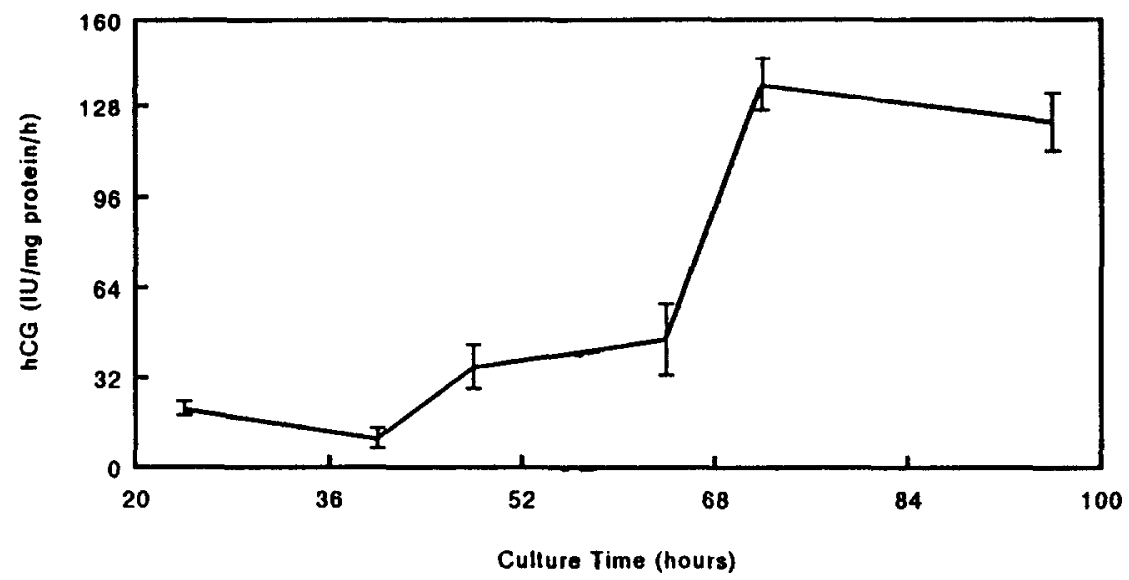

Fig. 1. hCG production by cytotrophoblasts in culture. Cells were isolated as described in Materials and methods and cultured in standard culture medium (control, - ). The medium was removed at indicated time points, centrifuged and hCG concentrations were measured in the supernatants using an ES-600 Boehringer Mannheim autoanalyzer. The medium was replaced by identical culture medium. Calculated were the hCG productions per hour, related to the dish protein content, during the period previous to the removal of the culture medium.

therefore acceptable (S.D. maximal 10\% of mean dish protein content; constant with time).

Up to 72-90 $\mathrm{h}$ after isolation, protein concentration remained stable and then fell significantly $\left(\alpha_{\mathrm{T}}<0.01\right)$. Protein concentration was independent of culture medium supplementation with hTf-2Fe (Fig. 2).

DNA concentration also declined (from 2.0 to $1.5 \mu \mathrm{g} / \mathrm{dish}$ ) after $72 \mathrm{~h}$ of culture $\left(\alpha_{T}<0.05\right)$ indicating cell loss. Nevertheless, DNA concentration was more stable than dish protein content which is depicted in Table 1 showing protein/DNA ratios. It can be concluded that cultured trophoblasts are viable for at least a period of up to $72-90 \mathrm{~h}$. Nevertheless, cultures for up to $160 \mathrm{~h}$ were possible without appreciable loss of protein and DNA if the placentae were obtained within 15 min of parturition.

\subsection{Transferrin receptor amounts}

The number of surface TfRs increased with time and were influenced by addition of hTf-2Fe to the medium (Fig. 3A), a process which was reversible (Fig. 3B). Cells cultured in iron-poor medium increased the number of surface TfRs to a significantly higher level (Fig. 3A) $\left(\alpha_{\mathrm{T}}<0.05\right)$. Replacement of iron-fortified medium by iron-poor medium led to a number of surface TfRs highly comparable with that of cells permanently cultured in iron-poor medium (Fig. 3B). In these experiments the number of surface TfRs was significantly higher $\left(\alpha_{T}<0.01\right)$ in cells cultured in iron-poor medium. In the cells cultured for $2.5 \mathrm{~h}$, surface TfRs were not detectable with the procedure used. Non-specific binding in these cells was always comparable with the total binding of ${ }^{125} \mathrm{I}-\mathrm{hTf}-2 \mathrm{Fe}$. 


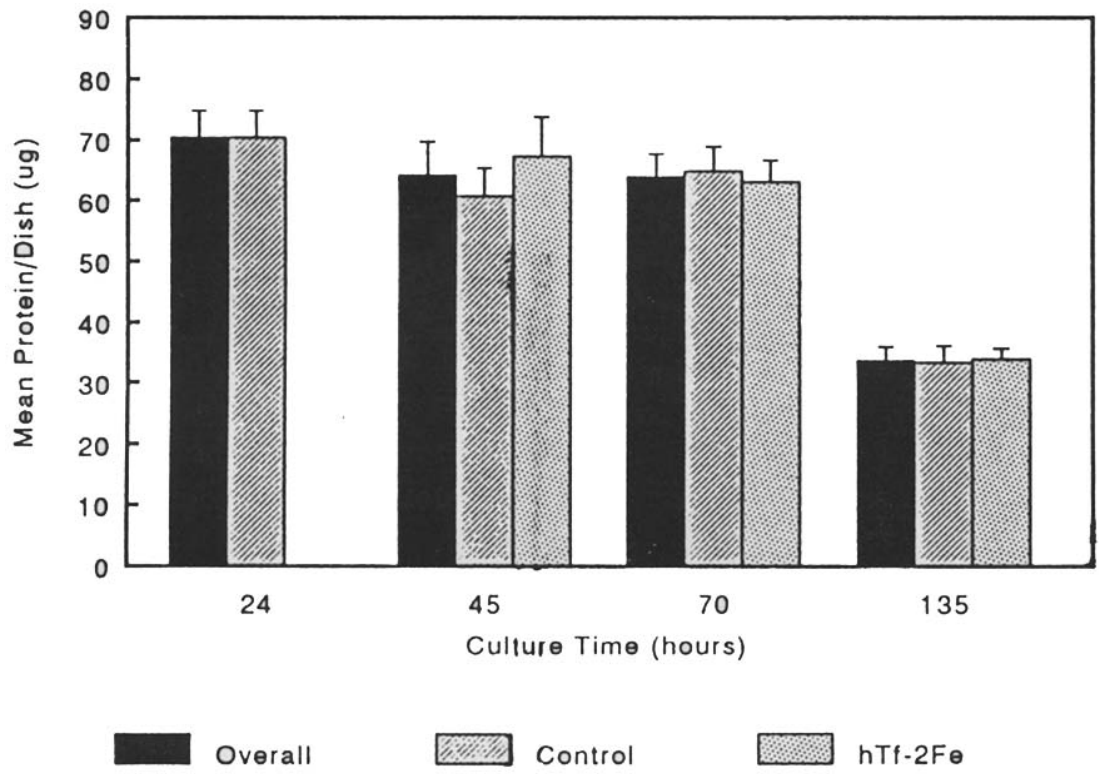

Fig. 2. Protein content of culture dishes. Influence of culture time and hTf-2Fe. Shown are the results of one experiment of a total of three. Although different in protein quantity (see Results) all three experiments were highly similar for the trend of protein loss. Trophoblasts were isolated and cultured as described in Materials and methods. At indicated culture times cells were harvested and lysed in distilled water. Depicted are the mean protein contents ( \pm S.D.) calculated from five dishes per series except for the overall means which were calculated from ten dishes.

Table 1

Mean protein/DNA ratios. Influence of culture time and hTf-2Fe

\begin{tabular}{|c|c|c|c|c|c|c|c|c|c|}
\hline \multirow{2}{*}{$\begin{array}{l}\text { Culture time } \\
\text { (day) }\end{array}$} & \multicolumn{3}{|c|}{ Experiment 1} & \multicolumn{3}{|c|}{ Experiment 2} & \multicolumn{3}{|c|}{ Experiment 3} \\
\hline & Mean & S.D. & $n$ & Mean & S.D. & $n$ & Mean & S.D. & $n$ \\
\hline 1 & 23.2 & 2.6 & 10 & 30.7 & 0.5 & 5 & 29.6 & 1.1 & 6 \\
\hline 2 & 22.3 & 5.0 & 9 & 31.9 & 2.7 & 9 & 30.2 & 4.0 & 6 \\
\hline 3 & 23.7 & 2.6 & 10 & - & 一 & - & 28.3 & 2.5 & 6 \\
\hline 4 & - & - & - & 22.3 & 1.9 & 13 & - & - & - \\
\hline 5 & - & - & - & 14.0 & 1.7 & 17 & 15.4 & 2.1 & 6 \\
\hline 6 & 15.0 & 1.9 & 10 & - & - & - & - & - & - \\
\hline 7 & - & - & - & 14.1 & 1.9 & 20 & - & - & - \\
\hline
\end{tabular}

Reproduced are the mean protein/DNA ratios $( \pm$ S.D., $n)$ of three highly similar experiments. Trophoblasts were isolated and cultured as described in Materials and methods. At indicated culture times (days) cells were harvested and lysed in distilled water. Dish protein- and DNA-contents were determined as described in Materials and methods. 

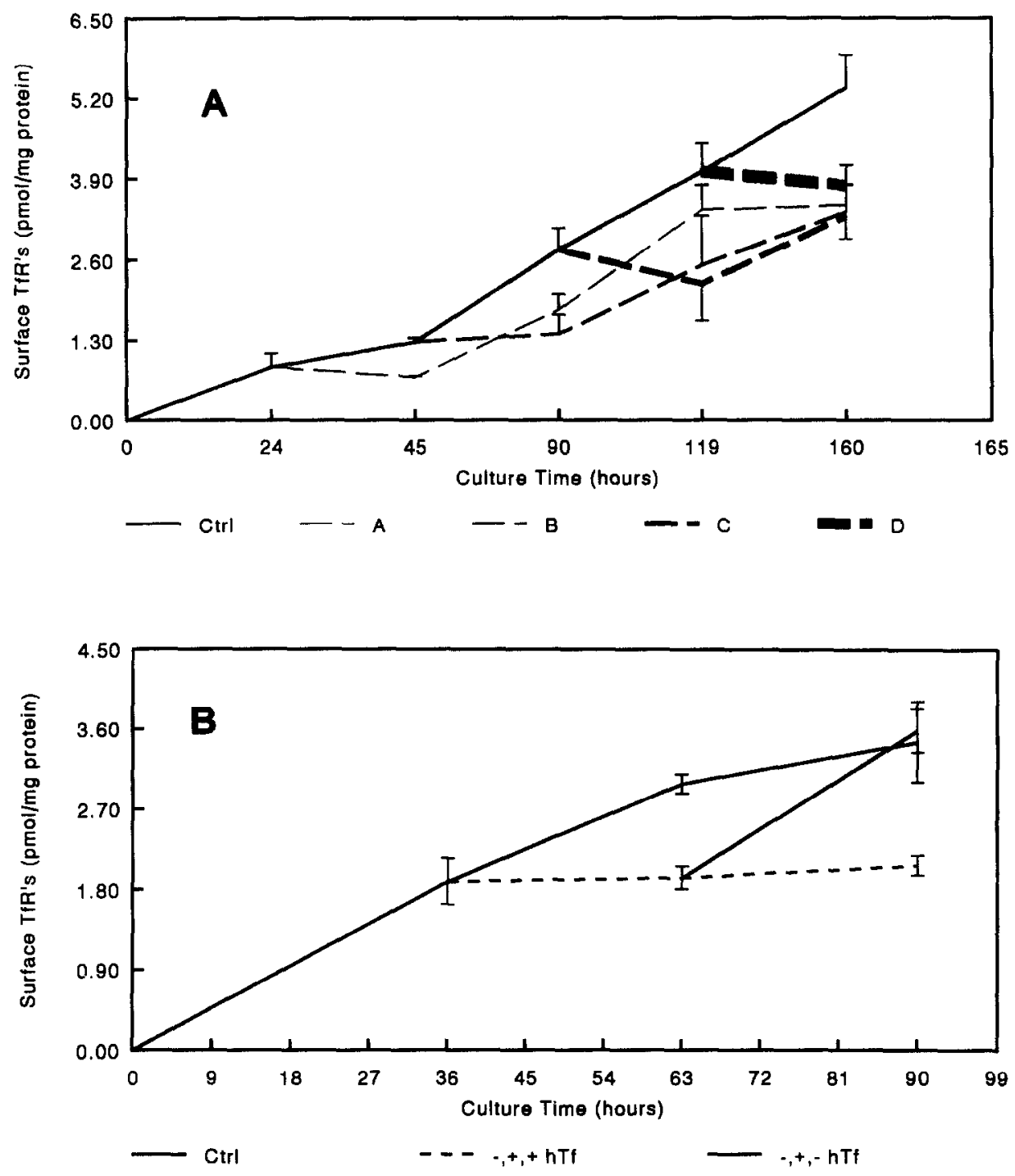

Fig. 3. Surface transferrin receptors. Influence of culture time and hTf-2Fe. (A) Trophoblasts were isolated as described in Materials and methods and cultured in iron-poor medium ( - , control series). After indicated culture periods culture was continued in medium containing hTf-2Fe $(---, 0.1 \mathrm{mg} / \mathrm{ml}$; Series A-D). Bars represent 1 S.D. Transferrin receptors were determined as described in Materials and methods. Results were corrected for non-specific binding by using parallel cultures incubated with a $100-$ times excess of unlabelled hTf-2Fe. (B) Culture conditions were identical to those described under Fig. 3A (control series: - - -; hTf-2Fe series:,,-++ ). In order to invest the reversibility of the regulation mechanism the hTf-2Fe fortified medium of five culture dishes was replaced by iron-poor medium at $65 \mathrm{~h}$ $(-,+,-$ series). Bars represent two standard deviations. Transferrin receptors were determined as described in Materials and methods. Results were corrected for non-specific binding by using parallel cultures incubated with a 100-times excess of unlabelled hTf-2Fe. 


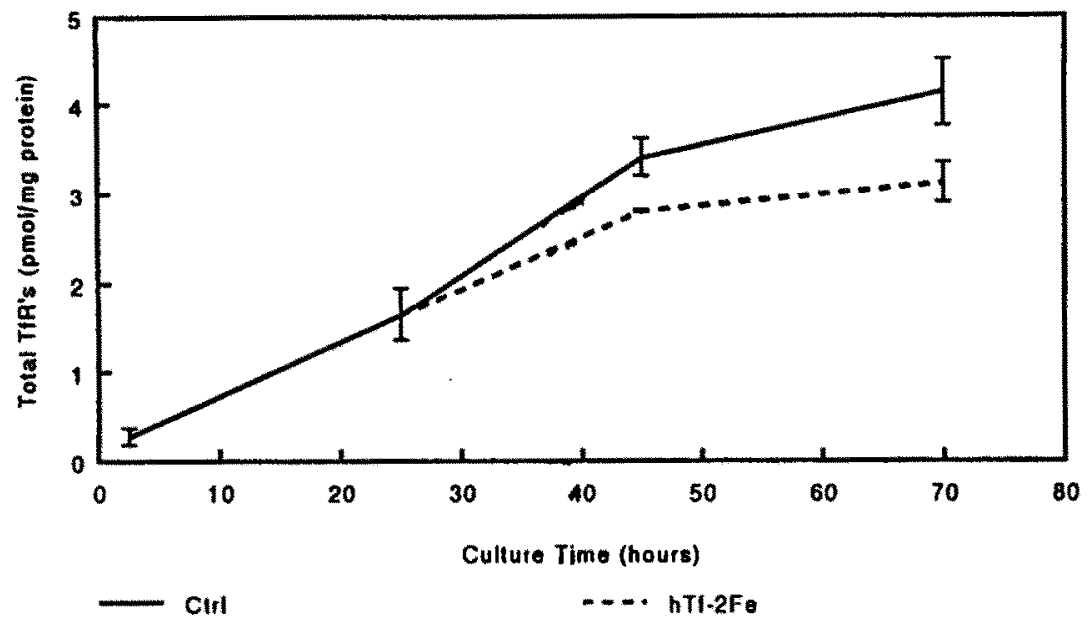

Fig. 4. Total transferrin receptors. Influence of culture time and hTf-2Fe. The results given are of one experiment highly similar to a total of three. Trophoblasts were isolated as described in Materials and methods and cultured in iron-poor medium (-). From $24 \mathrm{~h}$ on culture was continued in either ironpoor medium (-) or diferric human transferrin ( $\mathrm{hTf}-2 \mathrm{Fe}$ ) fortified medium $(---)(0.1 \mathrm{mg} / \mathrm{ml})$. At indicated culture times cells were harvested, lysed in $0.1 \%$ Triton X-100 and total TfRs were determined as described in Materials and methods. Results were corrected for aspecific binding by using parallel cultures incubated with a 100-times excess of unlabelled hTf-2Fe.

The total number of TfRs increased with time (Fig. 4). This increase was more clear cut if cells were cultured in iron-poor medium $\left(\alpha_{T}<0.02\right)$. In the cells cultured for $2.5 \mathrm{~h}$ very small numbers of TfRs were determined $(0.28 \mathrm{pmol}, \pm 0.03)$ TfRs/mg protein).

\subsection{Transferrin receptor distribution}

With time there was a redistribution of TfRs among the functionally different compartments in the trophoblast cell. Figure 5 shows the results obtained in one of three studies. The data show that about $45 \%$ of all TfRs actively participated in the endocytic cycle. The other part is stored and functionally inactive. This distribution was stable with time unless cells were cultured in iron-poor medium. In this case the percentage of active TfRs increased to about 56 , which was significantly higher than the $46 \%$ of the hTf-2Fe cultured series $(P<0.02)$. After $24 \mathrm{~h}$ about $30 \%$ of the TfRs were located on the cell surface. With time a significantly increasing part (up to $46 \%$ ) of the active TfRs were found on the cell membrane $(P<0.05)$, an increase which depended on hTf-2Fe supplementation of the culture medium. Finally, the percentage of surface-bound TfRs (of the total of TfRs) was significantly higher $(P<0.05)$ if cells were cultured in iron-free medium. The results indicate that this was mainly caused by an increase in the number of TfRs actively participating in the endocytic cycle. 


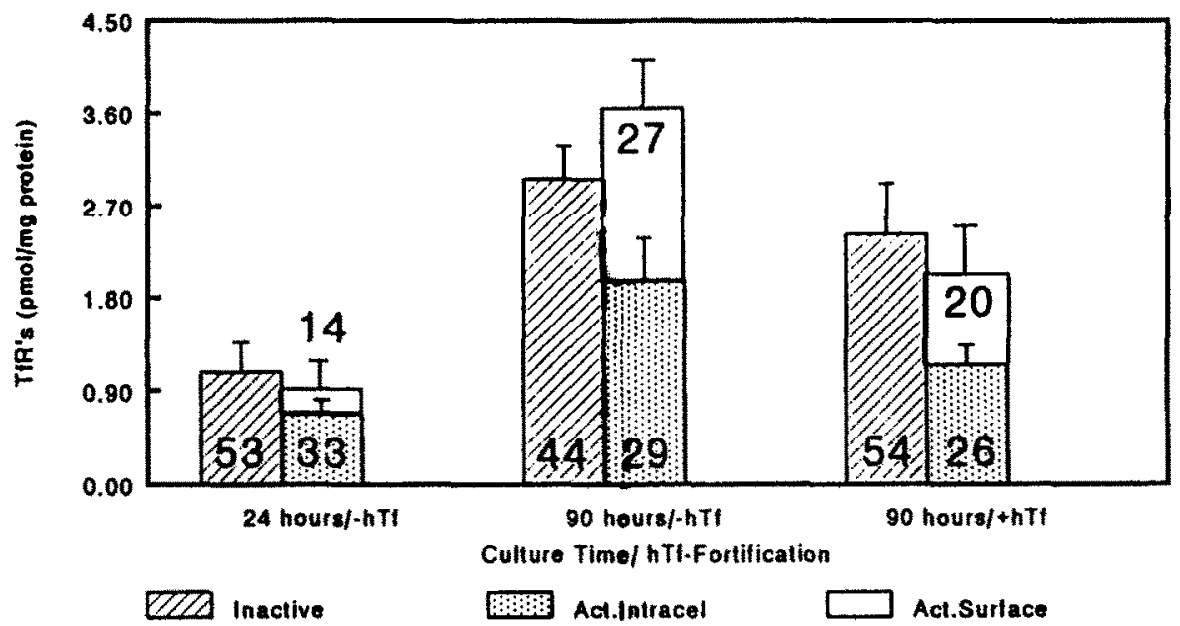

Fig. 5. Transferrin receptor distribution. Influence of culture time and hTf-2Fe. Shown are the results obtained in one experiment which is highly similar to a total of three. Trophoblasts were isolated and cultured as described in Materials and methods and cultured in iron-poor medium. After $24 \mathrm{~h}$ culture was continued in either iron-poor medium or human diferric transferrin (hTf-2Fe) supplemented medium $(0.1$ $\mathrm{mg} / \mathrm{ml}$ ). TfRs were determined as described in Materials and methods. Results were corrected for aspecific binding by using parallel cultures incubated with a 100-times excess of unlabelled hTf-2Fe. TfR sub-pool percentages are given by the numbers in the figure.

\section{Discussion}

Placental transport of iron has to be balanced very accurately. The first step in this process is the uptake of iron by syncytiotrophoblasts, which can be studied in in vitro cultured cytotrophoblasts $[10,20,33,34,36]$.

In culture, cytotrophoblasts express TfRs $[10,33,34]$ and start with the production of $\beta$-hCG [28,30-32]. The extent of TfR expression as well as of $\beta$-hCG production depends on cell quality which, on its turn, depends on the time loss between delivery of the placenta and the start of the isolation procedure [42]. In general, trophoblasts could be cultured for 72-90 h without significant loss of protein and DNA (Fig. 2, Table 1). Mean dish protein contents varied with cell isolation but were comparable with those published elsewhere $[36,43]$. In some experiments the culture period could be extended to approximately 8 days, though only if the placentae were obtained within $15 \mathrm{~min}$ after delivery. Because the protein-DNA ratio was stable during 72 $\mathrm{h}$ (Table 1) both can be used as standard for cell number. The combined loss of both protein and DNA, after approximately $90 \mathrm{~h}$, indicated cell loss.

In our studies TfR expression as well as hCG production increased until day 4-5 (Fig. 1). After this period hCG production fell [31] suggesting a metabolic/biochemical change whereas TfR expression continued to increase or at least stabilized. 
The rate of increase in surface TfRs was not essentially influenced by the availability of iron (Fig. 3A). Replacement of the standard culture medium by medium containing human diferric transferrin (hTf- $2 \mathrm{Fe}$ ) transiently reduced surface TfR numbers. Soon, however, the normal rate of increase was resumed (Fig. 3A), a process which was reversible (Fig. 3B). The rate of increase, as well as the numbers of TfRs, were highly comparable with those found by Kennedy et al. [34]. Their results showed that syncytium formation [30] is related to a reduction in surface TfR density. This seems to be supported by the earlier findings of van der Ende et al. [24] who demonstrated that CAMP analogons or cAMP-phosphorylase inhibitors induce BeWo cells to fuse and simultaneously to reduce surface TfR numbers. However cAMP-analogons, as such, neither stimulated the formation of syncytia nor modulated surface TfR numbers in cytotrophoblasts cultured in M199, though hCG production was increased 5- to 10-fold [20]. Furthermore, cytotrophoblasts in vivo lack TfRs $[44,45]$. We therefore think that the culture conditions used by Kennedy et al. [34] might induce differences in biochemical differentiation independent from the morphological differentiation.

Similar to the surface TfRs, total TfR numbers increased with time as depicted in Fig. 4, particularly if cells were cultured in iron-poor medium. Preliminary results suggested a stronger increase of total TfRs if cells were cultured in hTf-2Fe supplemented medium [35]. However with the carefully tested procedure described above, these results could not be reconfirmed. Based on the results on total TfR numbers we conclude that iron affects the TfR synthesis/breakdown ratio. However these results do not exclude the possibility of TfR redistribution, a process which, as a result of cell differentiation, has been demonstrated before in choriocarcinoma [24] and K562 erythroleukemic cells [25,46]. No changes in TfR amounts nor in TfR distribution, however, were found in HL-60 human leukemic cells during differentiation [47] and in different grades of macrophage activation [12], respectively.

Time and hTf-2Fe had different effects on the TfR synthesis/breakdown ratio and receptor redistribution (Fig. 5). Surface TfR numbers expressed as a percentage of the active TfR subpopulation increased significantly with time $(P<0.05)$ and were not influenced by the availability of iron. This might be an effect of cell differentiation. The final distribution is highly comparable with that in BeWo cells $[24,48]$. The size of the active TfR population, expressed as a percentage of total TfRs, was constant if, similar to the normal physiological situation, iron was available. Iron shortage caused TfRs to redistribute between the inactive and active receptor pool.

Within the pool of active TfRs there was a shift of TfRs to the surface, independent of iron availability, and therefore most likely caused by a process of differentiation similar to that in BeWo choriocarcinoma cells $[24,47]$. Surface TfRs might be increased to a pre-fixed percentage of the active receptor pool which has been suggested before [20].

The variation in the number of surface TfRs due to iron availability was independent of the differentiation process and can be explained by the shift of TfRs between the inactive and active pool. If, within the active TfR subpopulation, the distribution of TfRs over cell surface and interior remains stable this shift will automatically lead to an increase in surface TfRs. 
Trophoblasts could regulate iron uptake (and by this way transplacental iron transport) by variation of surface TfR numbers via changes in total TfR amounts and via redistribution of TfRs among the receptor pools. This is in accordance with the in vivo situation of iron-deficient mothers carrying fetuses with normal iron stores. Nevertheless, the results discussed in this article do not prove that there is indeed a causal relationship between the number of surface TfRs and iron uptake.

The effects of a differentiating iron transport system and of a regulation mechanism for iron uptake may interfere and should therefore be considered if transplacental iron transport processes are studied.

\section{References}

1 Bomford $\mathrm{AB}$, Munro $\mathrm{HN}$. Transferrin and its receptor: their roles in cell function. Hepatology 1985;5(5):870-875.

2 Huebers HA, Finch CA. The physiology of transferrin and transferrin receptors. Physiol Rev 1987;67(2):520-582.

3 de Jong G, van Dijk JP, van Eijk HG. The biology of transferrin. Clin Chim Acta 1990;190:1-46.

4 Dautry-Varsat A, Ciechanover A, Lodish HF. pH and the recycling of transferrin during mediated endocytosis. Proc Natl Acad Sci USA 1983;80:2258-2262.

5 Klausner RD, Ashwell G, van Renswoude J, Harford JB, Bridges KR. Binding of apotransferrin to K562 cells: explanation of the transferrin cycle. Proc Natl Acad Sci USA 1983;80:2263-2266.

6 Pearse BMF. Clathrin: a unique protein associated with intra-cellular transfer of membrane by coated vesicles. Proc Natl Acad Sci USA 1976;73:1255-1259.

7 van Renswoude J, Bridges KR, Harford JB, Klausner RD. Receptor mediated endocytosis of transferrin and uptake of iron in K562 cells. Identification of a non-lysosomal compartment. Proc Natl Acad Sci USA 1982;79:6186-6190.

8 Thorstensen K, Romslo I. Uptake of iron from transferrin by isolated rat hepatocytes. J Biol Chem $1988 ; 263: 8844-8850$.

9 Douglas GC, King BF. Receptor mediated endocytosis of ${ }^{125}$ I-labelled transferrin by human choriocarcinoma (JAR) cells. Placenta 1988;9:253-265.

10 Douglas GC, King BF. Uptake and processing of ${ }^{125} \mathrm{I}$-labelled transferrin and ${ }^{59} \mathrm{Fe}$-labelled transferrin by isolated human trophoblast cells. Placenta 1990;11:41-57.

11 Frazier JL, Casey JH, Yoffe M, Seligman PA. Studies of the transferrin receptor on both human reticulocytes and nucleated human cells in culture. J Clin Invest 1982;69:853-865.

12 Hamilton TA, Weiel JE, Adams DO. Expression of the transferrin recptor in murine peritoneal macrophages is modulated in the different stages of activation. J Immunol 1984;132(5):2285-2290.

13 Hirose-Kumagai A, Akamatsu $\mathbf{N}$. Change in transferrin receptor distribution in regenerating rat liver. Biochem Biophys Res Comm 1989;164(3):1105-1112.

14 Hentze MW. Translational regulation of ferritin biosynthesis by iron: a review. In: Albertini A, Lenfant $\mathrm{CL}$, Mannucci PM, Sixma JJ, eds. Biotechnology of plasma proteins. Curr. Stud. Hematol. Blood Transf. Basel: Karger, 1991;58:115-126.

15 Müllner EW, Kühn LC. A stem-loop in the 3' untranslated region mediates iron-dependent regulation of transferrin receptor mRNA stability in the cytoplasm. Cell 1988;53:815-825.

16 Rios E, Lipschitz DA, Cook JD, Smith NJ. Relationship of maternal and infant iron stores as assessed by determination of plasma ferritin. Pediatrics 1975;55:694-699.

17 Wallenburg HCS, van Eijk HG. Effect of oral iron supplementation during pregnancy on maternal and fetal iron status. J Perinat Med 1984;12:7-12.

18 Wong CT, Saha N. Inter-relationships of storage iron in the mother, the placenta and the newborn. Acta Obstet Gynecol Scand 1990;69(7-8):613-616.

19 van Dijk JP. Review article: regulatory aspects of placental iron transfer - a comparitive study. Placenta 1988;9:215-226. 
20 Bierings MB, Baert MRM, van Eijk HG, van Dijk JP. Transferrin receptor expression and the regulation of placental iron uptake. Mol Cell Biochem 1991;100:31-38.

21 Ward JH, Kushner JP, Kaplan J. Regulation of HeLa cell transferrin receptors. J Biol Chem 1982;257(17):10317-10323.

22 Davis RJ, Czech MP. Regulation of transferrin receptor expression at the cell surface by insulin-like growth factors, epidermal growth factor and platelet derived growth factor. EMBO J 1986;5(4):653-658.

23 Davis RJ, Corvera S, Czech MP. Insulin stimulates cellular iron uptake and causes the redistribution of intracellular transferrin receptors to the plasma membrane. J Biol Chem 1986;261(29):8708-8711.

24 van der Ende A, du Maine A, Schwartz AL, Strous GJ. Modulation of transferrin-receptor activity and recycling after induced differentiation of BeWo choriocarcinoma cells. Biochem J 1990;270:451-457.

25 Mulford CA, Lodish HF. Endocytosis of the transferrin receptor is altered during differentiation of murine erythroleucemic cells. J Biol Chem 1988;263:5455-5461.

26 Wiley HS, Kaplan J. Epidermal growth factor rapidly induces a redistribution of transferrin receptor pools in human fibroblasts. Proc Natl Acad Sci USA 1984;81:7456-7460.

27 Ward DM, Kaplan J. Mitogenic agents induce redistribution of transferrin receptors from internal pools to the cell surface. Biochem J 1986;238:721-728.

28 Kliman HJ, Nastler JE, Sernasi E, Sanger JM, Strauss III JF. Purification, characterization and in vitro differentiation of cytotrophoblasts from human term placentae. Endcrinology 1986;118(4): 1567-1582.

29 Nelson DM, Meister RK, Ortman-Nabi J, Sparks S, Stevens VC. Differentiation and secretory activities of cultured human placental cytotrophoblast. Placenta 1986;7:1-16.

30 Douglas GC, King BF. Differentiation of human trophoblast cells in vitro as revealed by immunocytochemical staining of desmoplakin and nuclei. J Cell Sci 1990;96:131-141.

31 Morrish DW, Siy O. Critical factors in establishing monolayer cultures of normal human placental cells in serum free medium. Endocr Res 1986;12(3):229-253.

32 Yagel S, Casper RF, Powell W, Parhar S, Lala PK. Characterization of pure human first-trimester cytotrophoblast cells in long term culture: growth pattern, markers, and hormone production. Am J Obstet Gynecol 1989;160(4):938-945.

33 Bierings MB, Adriaansen HJ, van Dijk JP. The appearance of transferrin receptors on cultured human cytotrophoblast and in vitro formed syncytiotrophoblast. Placenta 1988;9:387-396.

34 Kennedy ML, Douglas SC, King BF. Expression of transferrin receptors during differentiation of human placental trophoblast cells in vitro. Placenta 1992;13:43-53.

35 Starreveld JS, Abdoel AM, v Dijk JP, Kroos MJ, v Eijk HG. The effect of different iron compounds on transferrin receptor expression in term human cytotrophoblast cells. Biol Trace Elem Res 1992;35(1):55-63.

36 Bierings MB, Jones C, Adriaansen HJ, v Dijk JP. Transferrin receptors on cyto- and in vitro formed syncytiotrophoblast. Troph Res 1991;5:349-362.

37 Bürgisser E. Radioligand receptor binding studies: what is wrong with the Scatchard analysis. Trends Pharmacol Sci 1984;142-144.

38 Rao KK, Shapiro D, Mattia E, Bridges K, Klausner R. Effects of alterations in cellular iron on biosynthesis of the transferrin receptor in K562 cells. Mol Cell Biol 1985;5:595-600.

39 Bradford MM. A rapid and sensitive method for the quantification of microgram quantities of proteins utilizing the principles of protein-dye binding. Anal Biochem 1976;72:248-251.

40 Wang CS, Smith RL. Lowry determination of protein in the presence of triton X-100. Anal Biochem 1975;63:414-417.

41 Hukkelhoven MWAC, Vromans E, Markslag AMG, Vermorlen AJM. Research unit for cellular diffcrentiation and transformation. Anticancer Res 1981;1:341-344.

42 Klassen ME, Nachtigal MW, Cattini PA. Human chorionic somatomammotropin gene expression in primary placental cell cultures. Placenta 1989;10:321-329.

43 Nestler JE, Williams T. Modulation of aromatase and P450 cholesterol sidechain cleavage enzyme activities of human placental cytotrophoblasts by insulin like growth factor I. Endocrinology 1987;121(5): 1845-1052. 
44 Bulmer JN, Morrison L, Johnson PM. Expression of the proliferation markers Ki67 and transferrin receptor by human trophoblast populations. J Reprod Immun 1988;14:291-302.

45 Hsi B-I, Yeh CJ, Faulk WP. Human amniochorion: tissue specific markers, transferrin receptors and histocompatibility antigens. Placenta 1982;3:1-12.

46 Hunt RC, Ruffin R, Yang Y.S. Alterations in the transferrin receptor of human erythroleukemic cells after induction of hemoglobin synthesis. J Biol Chem 1984;259(15):9944-9952.

47 Enns CA, Mulkins MA, Sussman H, Root B. Modulation of the transferrin receptor during DMSOinduced differentiation. Exp Cell Res 1988;174:89-97.

48 van der Ende A, du Maine A, Simmons CF, Schwartz AL, Strous GJ. Iron metabolism in BeWo chorion carcinoma cells. J Biol Chem 1987;262(18):8910-8916. 